\title{
Vegetation community and species association of Castanopsis spp. at its habitat in the remnant forest of Cibodas Botanical Garden, Indonesia
}

\author{
DIAN RIDWAN NURDIANA ${ }^{1,2, \boldsymbol{v}}$, INOCENCIO E. BUOT, JR. ${ }^{1}$ \\ ${ }^{1}$ Plant Biology Division, Institute of Biological Science, College of Arts and Sciences, University of the Philippines Los Baños. College, Laguna \\ 4031, Philippines \\ ${ }^{2}$ Cibodas Botanical Garden, National Research and Innovation Agency Indonesia. Jl. Kebun Raya Cibodas, Sindanglaya, Cipanas, Cianjur 43253, West \\ Java, Indonesia. Tel./fax.: +62-263-512233/520419, `email: drnurdiana@up.edu.ph
}

Manuscript received: 25 August 2021. Revision accepted: 16 October 2021.

\begin{abstract}
Nurdiana DR, Buot JrIE. 2021. Vegetation community and species association of Castanopsis spp. at its habitat in the remnant forest of Cibodas Botanical Garden, Indonesia. Biodiversitas 22: 4799-4807. Castanopsis is one of the genera of Fagaceae with a large distribution in Indonesia. The genus can be found easily in Java, Sumatra, and Kalimantan. Several studies have found an association between Castanopsis and environmental factors dealing with diversity, dispersal, and propagation. So far, there has been no agreement on how Castanopsis interacts with other species within the same genus in nature, especially in the remnant forest under a fragmented state. The objectives of the study were to determine the vegetation associated with Castanopsis and whether each species of the genus Castanopsis co-occur within the remnant forest? A total of 60 plots have been studied in 3 different sites of the remnant forest. The nested sampling method was used to identify the trees, saplings and seedlings. Sixty-seven total species of trees, 140 species of saplings and 121 species of seedlings in the Cibodas Botanical Garden remnant forest were recorded. The diversity index for tree, sapling and seedling were 3.5, 3.9 and 4.1, respectively, while the evenness index for tree, sapling and seedling were $0.81,0.8$ and 0.85 respectively. The interspecific association of the genus Castanopsis was restricted to C. javanica x C. tungurrut. They are associated positively at the sapling stage with a Jaccard index of 0.2 . However, at the tree stage, there was no association out of the pair, $C$. javanica x C. tungurrut. Competition within genus Castanopsis occurred in the same habitat, though at a lesser degree which needs to be studied further. The dominance of many pioneer species (Oreocnide integrifolia (Gaudich.) Miq., Ostodes paniculata Blume, Cestrum aurantiacum Lindl. and others) at the tree stage had been evident. This implies that the Cibodas remnant forest is still in the process of succession towards a more stable climax state.
\end{abstract}

Keywords: Castanopsis, ecology, interspecific association, remnant forest

\section{INTRODUCTION}

Castanopsis as the third-largest genus under Fagaceae, is distributed widely across tropical and subtropical in Eastern and Southern Asia. Previous studies revealed that Castanopsis species were distributed abundantly, especially in South China and the Indo-China region (Chen et al. 2013; Cheuk and Fischer 2021). This genus has about 120 species in subtropical and tropical South Asia, 34 species in Malesia, and 24 species in Indonesia (Phengklai 2006; Purwaningsih and Polosakan 2016). Most of the genus Castanopsis is categorized as monoecious, evergreen and important taxa (Sun et al. 2014). They can grow from low to high altitude in the Western part of Indonesia, including Kalimantan, Sumatera, and Java. In West Java, there are four species occurring from 0 to $2500 \mathrm{~m}$ asl: Castanopsis argentea at 150-1500 m asl, C. javanica at 0-2000 m asl, Castanopsis tungurrut at $0-1800 \mathrm{~m}$ asl and $C$. acuminatissima at $760-2500 \mathrm{~m}$ asl (Purwaningsih and Polosakan 2016). C. javanica dominated the first layer stand in the forest of Mt. Pangrango and C. argentea in Mt. Gede (Mutaqien and Zuhri 2011; Yamada 1977) while $C$. tungurrut dominated the sub-montane forest in Gunung Halimun National Park (Simbolon 2001).
Castanopsis is also distributed in Cibodas Botanical Garden (CBG) located in West Java, Indonesia, particularly in the lower montane vegetation or sub-montane forest zone. This garden was established in 1852 during the Dutch colonialization, and it was an acclimatization site for plants collected in Bogor Botanical Garden including crops, and commodity plants. The garden has been the classical spot for botanical investigation in Indonesia with more than 8000 studies conducted (Mutaqien and Zuhri 2011). The location of CBG adjacent to Gede Pangrango National Park (GPNP) has an important ecological function. The location provides support for the existence of plant collection in the garden by providing natural predators, pollinators, water availability and nutrient support, like $C$. argentea providing shelter and host tree for epiphytic orchids (Farokhah et al. 2018) and repository of rich nutrients from the volcanic eruption of Mount Gede Pangrango, dominated by dystrandepts soil with low saturation, thick and black topsoil type (Whitten et al. 1996). This garden has a total land area of 84.9 hectares comprising forest and garden areas. The existence of remnant forests in CBG plays an important function as a research site and ecotourism. The total land area of 8.43 hectares of remnant forest is well known as a critical site to monitor forest dynamics in high mountain vegetation and the existence of exotic plants. 
In order to understand the community structure, function, formation, maintenance and succession of remnant forest, the interspecific association of dominant species will be informative. As described in the previous study, interspecific association will reveal how the habitat selection and mutual attraction or repellence of cooccurring species in a particular habitat ( $\mathrm{Su}$ et al. 2015). Understanding the interspecific association of native species in Cibodas remnant forest is less studied. There is no specific information revealing the function of association contributed to dynamic forest processes. A previous study (Baokun et al. 2019) revealed that the ratio of positive to negative association decreases with higher diameter classes of a given pair of species. This implied that the association occurs in the succession phase of forest rather than a mature forest.

The interspecific association has been viewed as a very important population attribute, dealing with the relationship among different species within a population and understanding the community's self-organizing assembly and succession ( $\mathrm{Lu}$ et al. 2007; $\mathrm{Xu}$ and Cai 2016; Zhang 2014). The association will represent the interaction of species to species and species to the environment. This information will be important for identifying the structure and dynamics of the community in nature.

Some factors contribute to the interspecific association, namely competition for resources, species herd protection, and dispersal limitation (Lan et al. 2012; Zhou et al. 2019). Whether the result of the association would be positive, negative or absent would depend on whether the two species select or avoid the same habitat or habitat factors (Ludwig and Reynolds 1998).

The ecological function of native species in Cibodas remnant forest is still questionable, particularly the Castanopsis species. Exploring their role will contribute to the information of the state of forest vegetation and how the interspecific relation within the genus affects to structure of vegetation in forests. In this present paper, the interspecific association of Castanopsis was examined to determine the interaction within the genus and its implication to the vegetation dynamics of the remnant forest. The information obtained would reveal how the dominant genus interacts with other members of the genus and the forest community.

\section{MATERIALS AND METHODS}

\section{Study site}

Three remnant forest sites of CBG were chosen with a total area of 8.430 ha consisting of Wornojiwo remnant forest 3.934 ha, Leuwigoong (Kompos) area 2.555 ha, and Jalan Akar 1.941 ha (Mutaqien and Zuhri 2011), see Figure 1. The location is on the eastern slope of Mount GPNP West Java, Indonesia. All remnant forest has more or less similar agro-climatic conditions with an average temperature of $20.6^{\circ} \mathrm{C}$, and an altitude between $1,300 \mathrm{~m}$ and $1,450 \mathrm{~m}$ above sea level.
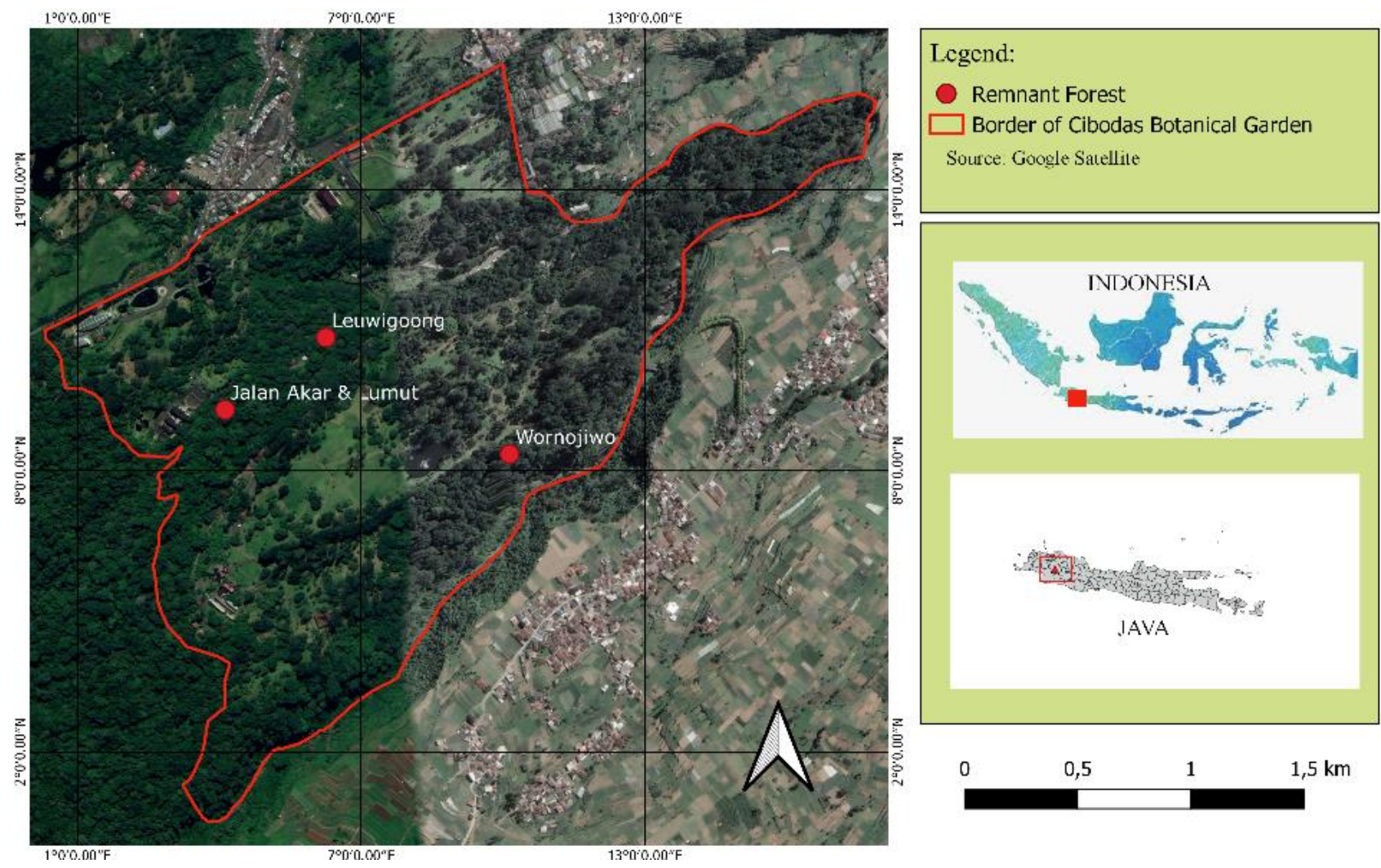

Figure 1. Map of Cibodas Botanical Garden's Remnant Forest, Cianjur District, West Java, Indonesia 


\section{Species sampling}

A nested plot technique was used in this research. The main plots measured $10 \times 10 \mathrm{~m}^{2}$ (for the trees) and within each $10 \times 10 \mathrm{~m}^{2}$, a $5 \times 5 \mathrm{~m}^{2}$ plot for the saplings was established. Then within the $5 \times 5 \mathrm{~m}^{2}$ plot, a $1 \times 1 \mathrm{~m}^{2}$ plot was established on the north-western corner for the seedling (Figure 2). The plots were selected randomly and coordinates were recorded using GPS. The number of plots established varied depending on the total land area of the forest. The larger the area of the remnant forest, the higher number of plots were established. There were 30 plots for Wornojiwo, 20 for Leuwigoong, and 10 for Jalan Akar remnant forests.

All trees with stem diameter at breast height (DBH) of $1.30 \mathrm{~m}$ height and $\geq 5 \mathrm{~cm}$ stem diameter were recorded with the total height, and first branch height. All trees were tagged, identified and voucher specimens were collected for unidentified species. Samplings of saplings were done by counting individuals within subplot $5 \times 5 \mathrm{~m}^{2}$ on the northern quadrant of the $10 \times 10 \mathrm{~m}^{2}$ quadrat. Saplings in this study were all individuals with DBH of $\leq 5 \mathrm{~cm}$ and height of $\geq 1 \mathrm{~m}$. These were surveyed, identified and were recorded accordingly (Raymundo et al. 2018). A sampling of herbs and seedlings were done by counting all individuals with a height of $\leq 1 \mathrm{~m}$ within the $1 \times 1 \mathrm{~m}^{2}$ quadrat. Density, dominance and frequency values were calculated to obtain the importance value of all species, index of evenness, and the Shannon-Wiener diversity index (H') following (Pielou 1972; Dogra et al. 2009).

\section{Interspecific association measurement}

Species presence and absence were noted and recorded to measure the interspecific association following ( $\mathrm{Su}$ et al. 2015; Zuhri 2017). The association coefficient (AC) was calculated based on the $2 \times 2$ contingency table to quantify the interspecific association of each species pair. Then the data were tested by chi-square $\left(\mathrm{x}^{2}\right)$ and Jaccard' association index following (Pielou 1972; Dogra et al. 2009). The association was selected specifically only to species of Castanopsis present in all remnant forest plots.

\section{Data analysis}

Vegetation analysis of the study site was conducted by measuring density, frequency, dominance, Importance Value Index, Shannon-Wiener diversity index and index of evenness. The analysis figured out the condition of the remnant forest where the Castanopsis was found while assessing the association of species under genus Castanopsis, $2 \times 2$ contingency table, chi-square test and Jaccard index was applied.

\section{Association coefficient using $2 \times 2$ Contingency table}

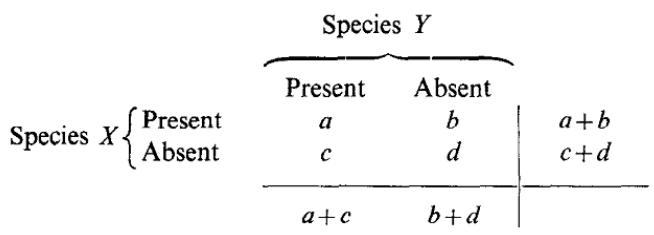

To test the null hypothesis of independence of $2 \times 2$ table, the chi-square test statistic was used.

\section{Chi-square $\left(x^{2}\right)$ test}

$$
\begin{gathered}
x^{2}=\frac{[a-E(a)]^{2}}{E(a)}+\frac{[b-E(b)]^{2}}{E(b)}+\frac{[c-E(c)]^{2}}{E(c)}+\frac{[d-E(d)]^{2}}{E(d)} \text { (Eq. 1) } \\
E(a)=\frac{(a+b)(a+c)}{n} \quad E(b)=\frac{(a+b)(b+d)}{n} \\
E(c)=\frac{(a+c)(c+d)}{n} \quad E(d)=\frac{(b+d)(c+d)}{n}
\end{gathered}
$$

The significance of the chi-square test statistic is determined by comparing it to the theoretical chi-square distribution $(\mathrm{P}=0.05, \mathrm{df}=1)$. If $\mathrm{x}^{2}$ test $>\mathrm{x}$ table, the null hypothesis is rejected that the co-occurrence of Castanopsis and the paired species is dependent. At the same time, to determine the type of association by comparing the value of observed a to that of expected a. Where a $>E(a)$ refers to positive association type (the pair of species occurred together more than expected if independent); a $<E(a)$ refers to negative association type (the pair of species occurred together less often than expected if independent).

To measure the degree of association, the Jaccard index was employed. Where 0 is equal to no association and one is equal to complete or maximum association.

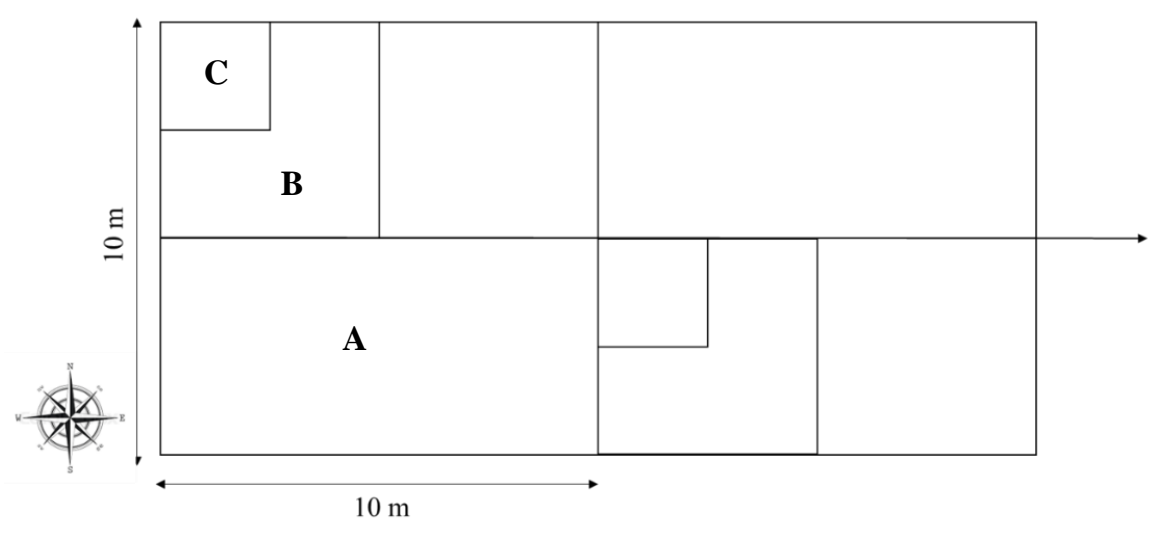

Figure 2. Plot design: A. $10 \times 10 \mathrm{~m}^{2}$, B. $5 \times 5 \mathrm{~m}^{2}$, C. $1 \times 1 \mathrm{~m}^{2}$ respectively 
Jaccard index

$$
S j=\frac{a}{a+b+c}(\text { Eq. 2) }
$$

Where: $a$, refers to the number of species in both sites; $b$, refers to the number of species on the second site only; $c$, refers to the number of species on the first site only.

\section{RESULTS AND DISCUSSION}

\section{Vegetation analysis of Cibodas remnant forest}

The vegetation of Cibodas remnant forest consisted of 67 species of tree, 140 species of sapling and 121 species of seedlings. Dominant tree families included Rubiaceae, Moraceae Lauraceae, Urticaceae and Fagaceae. Among the species, the highest number was Oreocnide integrifolia (61 individuals), Ostodes paniculata (53 individuals), Cestrum aurantiacum (23 individuals), Castanopsis argentea (20 individuals), Liquidambar excelsa (13 individuals), Macropanax dispermus (13 individuals) and Castanopsis javanica (11 individuals). The condition of CBG remnant forest has 39\% similarity to the natural forest of Gede Pangrango National Parks and a good representation of National Park (Mutaqien and Zuhri 2011). The remnant forest was fragmented in the past, due to human intervention in the management of the botanical garden and natural disasters such as the formation of forest gaps caused by the hurricane in 1976 and 1984 that allowed the light penetration and facilitated the fast-growing species (Mutaqien and Zuhri 2011). There is an only little number of emergent and big trees such as L. excelsa in this location which allows the Fagaceae as non-emergent trees to dominate and co-dominate. In the tree stratum dominant trees in this area are Oreocnide and Ostodes in line with a previous report by Mutaqien and Zuhri (2011).

The result of the diversity index and index of evenness is shown in Table 1. A closer examination of the table would show that the diversity index of the vegetation at various stratum, had been relatively the same, the tree diversity index is 3.5 with index of evenness, 0.81 . On the other hand, the diversity index for saplings and seedlings is 3.9 and 4.1 respectively. This more or less stable diversity and evenness index imply the species composition in a various stratum is the same in the entire study area with an average 0.8 index of evenness.
What is prominent in this table is the general pattern of dominance by seedlings. Based on our field observations, the forest floor was dominated by introduced species that covered most of the remnant forest such as Goeppertia lietzei (Marantaceae) and C. aurantiacum (Solanaceae). That can affect the forest structure community in the future and inhibit the regeneration of native species by forming dense monocultures under the forest canopy, altering the decomposition and reducing light availability (Larpkern et al. 2011; Trammell et al. 2012).

Further data analysis showed that the total number of tree species in each plot was varied, being 42,37 and 30 respectively for Wornojiwo, Leuwigoong (Kompos) and Jalan Akar and Lumut forest. C. argentea was found in all sampling sites as seen in Table 2, while the other species of Castanopsis is absent. There are several factors that contribute to the presence of $C$. argentea in the entire study site, both environmental and biological factors. $C$. argentea is a less selective growth site and prefers to grow in dry and fertile soil with stoniness (Wibowo 2006). It is probably Cibodas remnant forest meets the ideal condition for the optimum growth of $C$. argentea with environmental parameters range value for temperature $22.92-24.60^{\circ} \mathrm{C}$, soil humidity $39.9-76.7 \%$, air humidity $61.50-88.14 \%$, slope 5 $90^{\circ}$, litter thickness 3.8-6.3, and light intensity $74-80 \%$ and typic hapludand type soil (Wibowo 2006; Efendi et al. 2017).

The biological constraint in this area is the presence of introduced species, such as $C$. aurantiacum which was observed dominantly in all sampling sites in this remnant forest. This species has been recorded as invasive due to its impact on native flora in the ecosystem as described by (Junaedi 2012). On the forest floor, the remnant forest was dominated by G. lietzei (Marantaceae) which can inhibit the regeneration of native species in those areas while sapling stratum was dominated by Plectocomia elongata (Arecaceae).

Table 1. Diversity index and Index of evenness species in Cibodas remnant forest

\begin{tabular}{crcc}
\hline Parameter & \multicolumn{1}{l}{$\begin{array}{l}\text { Diversity } \\
\text { Species }\end{array}$} & Index & Index of Evenness \\
\hline Tree & 3.5 & 0.81 \\
Sapling & 3.9 & 0.8 \\
Seedling & 4.1 & 0.85 \\
\hline
\end{tabular}

Table 2. The tree species are found in the remnant forest in three different sites. The highest dominant species are marked by an asterisk and written bold based on the Importance Value Index

\begin{tabular}{|c|c|c|c|}
\hline Sampling site & 1 & 2 & 3 \\
\hline Altitude (m asl) & $1350-1417$ & $1312-1358$ & $1349-1419$ \\
\hline Coordinate & $06^{\circ} 44^{\prime} 79^{\prime \prime} \mathrm{S} ; 107^{\circ} 06^{\prime} 70^{\prime \prime} \mathrm{E}$ & 0643'63'’S; 10704'32'’'E & $06^{\circ} 44^{\prime} 29^{\prime \prime} \mathrm{S} ; 107^{\circ} 03^{\prime} 96^{\prime \prime} \mathrm{E}$ \\
\hline $\mathrm{pH}$ & $6.5-7$ & $6.8-7$ & $6.9-7$ \\
\hline Plot number & 30 & 20 & 10 \\
\hline Name of place & Wornojiwo & Leuwigoong & Jalan Akar and Lumut \\
\hline Number of species & 42 & 37 & 30 \\
\hline Maximum DBH $(\mathrm{cm})$ & 196.1 & 134 & 143.3 \\
\hline Maximum height (m) & 50 & 40 & 40 \\
\hline
\end{tabular}




\begin{tabular}{|c|c|c|c|c|}
\hline \multirow{2}{*}{ Family } & \multirow{2}{*}{ Species } & \multicolumn{3}{|c|}{ Importance value } \\
\hline & & 1 & 2 & 3 \\
\hline \multirow{3}{*}{ Actinidiaceae } & Saurauia pendula Blume & 1.27 & - & 1.11 \\
\hline & Saurauia bracteosa DC. & - & 2.57 & - \\
\hline & Saurauia reinwardtiana Blume & 0.63 & 0.86 & 1.11 \\
\hline Altingiaceae & Liquidambar excelsa Noronha & 3.17 & 1.71 & 6.66 \\
\hline \multirow{2}{*}{ Annonaceae } & Polyalthia subcordata (Blume) Blume & 2.54 & - & - \\
\hline & Orophea hexandra Blume & - & - & 2.23 \\
\hline Apocynaceae & Rauvolfia javanica Koord. \& Valeton & - & 0.86 & - \\
\hline \multirow[t]{3}{*}{ Araliaceae } & Macropanax dispermus (Blume) Kuntze & 6.95 & 0.86 & 1.11 \\
\hline & Brassaiopsis glomerulata (Blume)Regel & 0.63 & 3.43 & - \\
\hline & Trevesia sundaica Miq. & 0.63 & 0.86 & - \\
\hline Asteraceae & Strobocalyx arborea (Buch.-Ham.) Sch.Bip. & 0.63 & - & - \\
\hline Cannabaceae & Trema orientale $(\mathrm{L}$.$) Blume$ & - & 1.71 & 4.45 \\
\hline Celastraceae & Euonymus indicus B. Heyne ex Wall. & 1.27 & - & - \\
\hline Cornaceae & Alangium rotundifolium (Hassk.) Bloemb. & - & 0.86 & 1.11 \\
\hline \multirow[t]{2}{*}{ Elaeocarpaceae } & Sloanea sigun (Blume) K.Schum. & 1.90 & 1.72 & 1.11 \\
\hline & Elaeocarpus fleuryi A. Chev. Ex Gagnep & 0.63 & 0.86 & - \\
\hline \multirow{2}{*}{ Euphorbiaceae } & Ostodes paniculata Blume * & 19.62 & 12.86 & 7.77 \\
\hline & Mallotus sp. & - & - & 1.11 \\
\hline \multirow[t]{4}{*}{ Fagaceae } & Castanopsis argentea (Blume) A. DC. * & 6.98 & 4.29 & 4.44 \\
\hline & Castanopsis javanica (Blume) A. DC. & 5.06 & - & 3.31 \\
\hline & Castanopsis tungurrut (Blume) A. DC. & 3.17 & - & 2.23 \\
\hline & Lithocarpus pseudomoluccus (Blume) Rehder & 0.63 & 0.86 & - \\
\hline Juglandaceae & Engelhardia serrata Blume & 0.63 & - & - \\
\hline \multirow[t]{5}{*}{ Lauraceae } & Machilus rimosa Blume & 1.90 & - & - \\
\hline & Cryptocarya ferrea Blume & 0.63 & 0.86 & - \\
\hline & Cinnamomum burmanni (Nees \& T. Nees) Blume & 0.63 & - & - \\
\hline & Neolitsea javanica (Blume) Backer & 0.63 & - & - \\
\hline & Phoebe grandis (Nees) Merr. & - & - & - \\
\hline \multirow[t]{2}{*}{ Magnoliaceae } & Magnolia montana (Blume) Figlar & 2.53 & - & - \\
\hline & Magnolia sumatrana var. glauca (Blume) Figlar \& Noot. & - & 0.86 & - \\
\hline Malvaceae & Sterculia sp. & 0.63 & - & - \\
\hline \multirow[t]{3}{*}{ Meliaceae } & Toona sinensis (Juss.) M.Roem. & 1.27 & 2.58 & - \\
\hline & Dysoxylum excelsum Blume & - & 1.72 & - \\
\hline & Dysoxylum nutans (Blume) Miq. & 1.27 & - & - \\
\hline Metteniusaceae & Platea latifolia Blume & - & 0.86 & 1.11 \\
\hline Moraceae. & Ficus ribes Reinw. ex Blume & 1.27 & 2.58 & 5.55 \\
\hline & Ficus variegata Blume & - & 0.86 & 1.11 \\
\hline & Ficus grossularioides Burm.f. & - & 1.71 & - \\
\hline & Ficus heterophylla L.f. & - & 0.86 & - \\
\hline & Ficus involucrata Blume & - & 0.86 & - \\
\hline & Ficus fistulosa Reinw. ex Blume & - & 0.86 & - \\
\hline Myrtaceae . & Syzygium pycnanthum Merr. \& L.M.Perry & - & 4.30 & 1.11 \\
\hline & Syzygium racemosum (Blume) DC. & 1.26 & - & 5.53 \\
\hline Phyllanthaceae & Bridelia insulana Hance & 0.63 & 0.86 & - \\
\hline & Antidesma tetrandrum Blume & - & - & 1.11 \\
\hline Primulaceae & Myrsine hasseltii Blume ex Scheff. & - & - & 1.11 \\
\hline Proteaceae & Helicia serrata (R.Br.) Blume & 0.63 & - & 2.23 \\
\hline Rosaceae & Prunus arborea (Blume) Kalkman & - & 4.30 & - \\
\hline Rubiaceae & Neonauclea lanceolata (Blume) Merr. & - & 0.86 & 2.23 \\
\hline & Pavetta montana Reinw. ex Blume & 1.26 & - & 1.11 \\
\hline & Coffea sp. & 0.63 & 0.86 & - \\
\hline & Lasianthus laevigatus Blume & 1.27 & - & - \\
\hline & Neonauclea excelsa (Blume) Merr. & 0.63 & - & - \\
\hline Sabiaceae & Meliosma pinnata (Roxb.) Maxim. & - & 1.72 & 1.11 \\
\hline Salicaceae . & Flacourtia rukam Zoll. \& Moritzi & 0.63 & - & 1.11 \\
\hline Sapindaceae & Acer laurinum Hassk. & 0.63 & - & - \\
\hline Solanaceae & Cestrum aurantiacum Lindl. * & 6.96 & 4.29 & 7.76 \\
\hline Staphyleaceae & Dalrympelea sphaerocarpa (Hassk.) Nor-Ezzaw. & 5.06 & 4.30 & 2.21 \\
\hline & Turpinia montana (Blume) Kurz & 0.63 & - & - \\
\hline Symplocaceae & Symplocos guianensis (Aubl.) Gürke & - & - & 1.11 \\
\hline Theaceae & Schima wallichii (DC.) Korth. & 1.27 & 0.86 & - \\
\hline & Pyrenaria serrata Blume & - & - & 1.13 \\
\hline Urticaceae & Oreocnide integrifolia (Gaudich.) Miq. * & 6.33 & 25.62 & 27.59 \\
\hline & Dendrocnide stimulans (L.f.) Chew & - & 3.42 & - \\
\hline & Oreocnide sp. & 6.33 & - & - \\
\hline Viburnaceae & Viburnum lutescens Blume & - & 1.71 & - \\
\hline & Viburnum sambucinum Reinw. ex Blume & 0.63 & - & - \\
\hline
\end{tabular}


Castanopsis was less abundant in sapling and seedling as described in Table 3. There are several parameters that contribute to the low regeneration of Castanopsis, namely predation and competition. In a previous study of Castanopsis kawakamii forest, low regeneration and seedling growth was reported to be influenced by the low total nitrogen and total phosphorus in the soil as well as the presence of allelopathy (Jin et al. 2019) brought about by invasives usually. Another study by Wibowo (2006) revealed the dominance of Castanopsis decrease due to low phosphorus on the soil and their association with mycorrhiza. The over-harvesting is also contributed to the low regeneration of Castanopsis in this area. Two species of Castanopsis; $C$. argentea and $C$. javanica are edible, and the nuts are frequently being consumed by local people by roasting and boiling them. During our study, we can find the exocarp of Castanopsis abundantly without seed in the forest. It can be assumed the nuts are eaten by animals or harvested by humans.

Castanopsis usually grows in clumps and are distributed unevenly in different altitudes and the numbers tend to decrease in higher altitudes. Most of the succession stage of Castanopsis is low, due to low regeneration, overharvesting or the presence of introduced species in the forest, such as the abundance of $C$. aurantiacum. In the case of $C$. argentea previous study points out that environmental factor contributes to dominance and distribution of $C$. argentea. About $61.5 \%$ of $C$. argentea distribution and dominance is affected by altitude, cation exchange capacity, temperature and $\mathrm{N}$ total in the soil (Hilwan and Irfani 2018).

As a secondary forest, pioneer tree species had the highest importance value due to the gap that paved more sunlight penetration enhancing prolific growth in the forest community. A previous study revealed that canopy openness, herbivore and temperature regime would influence the survival rate of seedling of pioneer tree (Goodale et al. 2014; Xia et al. 2016). Ostodes paniculata has the highest importance value index. This species has been identified as a pioneer species in a fragmented forest and has a higher germination rate compared to Dipterocarpus macrocarpus, Canarium strictum, Beilschmiedia assamica in tropical rainforest (Panna and Sundriyal 2017). As described by (Mutaqien and Zuhri 2011) that $O$. paniculata were dominated in CBG remnant forest together with Villebrunea rubescens because of their character as the fast-growing tree, light is demanding and short-lived. Unlike the pioneer species, the native species C. argentea is also dominated in the remnant forest. This is illustrated by the presence of $C$. argentea as the third most important tree species in the remnant forest (IVI=11.51). Aside from their dominance in fragmented forests, a previous study showed that $C$. argentea has a higher photosynthetic rate and $\mathrm{CO}_{2}$ assimilation than other species such as C. acuminatissima, Altingia excelsa and Lithocarpus sp. The transpiration rate of $C$. argentea was reported 3.22 molm $^{-2} \mathrm{~s}^{-1}$ and the $\mathrm{CO}_{2}$ assimilation was 9.333 $\mu \mathrm{mol} / \mathrm{m}^{2} / \mathrm{s}$ (Hidayati et al. 2012). The high photosynthetic rate of the species implied that it is well adapted in the tropics, with high light intensity and soil moisture. As regards adaptation to high altitude, Castanopsis has cyclocytic stomata with thickened subsidiary cells, trichomes and double epidermal cell layers within the same leaf (Liu et al. 2009; Aoki et al. 2014).

Unlike the other species of Castanopsis, C. javanica (11 individuals) and $C$. tungurrut (7 individuals), were found only in 2 sites, Wornojiwo and Jalan Akar remnant forest and absent in the Leuwigoong remnant forest. The environmental characteristics of all remnant forests were the same, with altitude ranging from 1,300 to $1,400 \mathrm{~m}$ asl and soil $\mathrm{pH}$ of 6.5-7. It can be assumed that the gap size of Leuwigoong is smaller than the rest of the location which affects light availability to promote the germination in this area as described in a previous study of the effect of gap size on regeneration of $C$. kawakamii is highly promoted by gap size, the larger gap size the higher regeneration rate (Buajan et al. 2018).

Table 3. The five remnant forest species with the highest Important Value Index on different life stages

\begin{tabular}{lllc}
\hline Life stage & Species & Family & $\begin{array}{c}\text { IVI } \\
\text { (Important Value }(\%)) \\
\text { =Rden+Rfr+Rdom }\end{array}$ \\
\hline Tree & Ostodes paniculata Blume & 29.07 \\
& Oreocnide integrifolia (Gaudich.) Miq. & Euphorbiaceae & 27.74 \\
& Castanopsis argentea (Blume) A. DC. & Urticaceae & 11.51 \\
& Cestrum aurantiacum Lindl. & Fagaceae & 11.28 \\
& Dalrympelea sphaerocarpa (Hassk.) Nor-Ezzaw. & Solanaceae & 8.01 \\
Sapling & Staphyleaceae & & 32.78 \\
& Plectocomia elongata Mart. ex Blume & Arecaceae & 26.88 \\
& Polyalthia subcordata (Blume) Blume & Annonaceae & 21.97 \\
& Etlingera coccinea (Blume) S.Sakai \& Nagam. & Zingiberaceae & 15.87 \\
& Calamus heteroideus Blume & Arecaceae & 12.34 \\
Seedling & Urticaceae & \\
& Oreocnide integrifolia (Gaudich.) Miq & & 13.50 \\
& Goeppertia lietzei (É.Morren) Saka & Marantaceae & 12.24 \\
& Dicliptera undulata (Vahl) Karthik. \& Moorthy & Acanthaceae & 11.53 \\
& Alocasia sp. & Araceae & 9.93 \\
& Cynodon sp. & Poaceae & 7.42 \\
\hline
\end{tabular}


In general, Castanopsis growth cycle and diversity were influenced by the physical and chemical characteristics of the habitat as described by (Purwaningsih and Polosakan 2016; Chu et al. 2020; He et al. 2020). Castanopsis is well adapted in high altitude with high precipitation, a soil composition of $11.2 \%$ sand, $47.3 \%$ clay and $41.5 \%$ silt, $40 \%$ slope, and $60-97 \%$ relative humidity. Low germination rate and high pressure of habitat degradation is another factor intercorrelated with rarity. Another factor influencing the low regeneration is the high intensity of harvesting by local people, herbivores and decay (Wang et al. 2019).

The presence of three species of Castanopsis in the remnant forest serves as a shelter for other species while providing nutrients for the understory vegetation as described in the previous study. It provides suitable microenvironments for late-successional species in the community as illustrated in the case of Castanopsis chinensis and contribute to the nutrient flow to maintain the soil fertility (Wang et al. 2012; Shrestha et al. 2018).

Overall, the vegetation condition of the present remnant forest is almost the same, there is very little difference compared to previous data as described by (Mutaqien and Zuhri 2011). It can be assumed that the dynamics in the CBG remnant forest vegetation are stable.

\section{Interspecific association of Castanopsis}

The interspecific association is an important interaction and process related to succession in a community, which can promote to form of the aggregated distribution of species (Lan et al. 2012). A positive association was found in Castanopsis javanica $\mathrm{x}$ Castanopsis tungurrrut on the sapling stage $\left(\mathrm{X}^{2}>3.84\right)$. It revealed that these species cooccurred on the same habitat and facilitated each other's survival and shared similar resources (Su et al. 2015). This implied that both species supported each other through a similar capacity to adapt to environmental pressures, facilitate each other in ameliorating the abiotic condition by physical presence in the remnant forest with the high competition due to the presence of invasive species, and forest gap (Brooker and Callaghan 1998; García-Cervigón et al. 2013). This positive interaction could lead to an increasing plant density, increasing litter accumulation, better soil stability, decreasing evaporative water loss, protecting from disturbances and stress. Hence, this good adaptation results in dominance in the community. As revealed in a previous study by (Mutaqien and Zuhri 2011), $C$. argentea had been dominant in CBG remnant forest especially on its tree life form with a DBH of $>80 \mathrm{~cm}$. The species with significant positive or negative association generally, are the keystone species in the community (Zhang 2014). This is the case of $C$. javanica $\mathrm{x} C$. tungurrut in the present study (Table 4) showing a positive association.

A negative association was shown on $C$. argentea with $C$. javanica and with $C$. tungurrut despite the dominance of C. argentea in all the plots (Tables 3 and 4.). The dominance of a particular species is the consequence of high competition. It can be hypothesized that the dominance of $C$. argentea in all sampling sites as the fragmented forest is triggered by wide dispersal (edible by animals especially rodents), the character of being less selective on habitat types, low genetic differentiation and favorable environmental parameters (Wang et al. 2011; Wibowo 2006). Having the third highest importance value among trees, $C$. argentea is an important species in the ecosystem with a high risk of extinction due to a low rate of germination and habitat degradation.

In general, all the species of Castanopsis are not associated with each other, this can be inferred that Castanopsis is a relatively independent distribution. This condition will result in a low population and possible future threats of extinction. Based on Table 4, only C. javanica and $C$. tungurrut showed a positive association at the sapling stage. Probably, those species have similar strategies in responding to the environmental factors prevailing in the area. Previous observations revealed that positive association has the capacity to alleviate the stress brought about by the constraints of the environment. The absence of $C$. acuminatissima is questionable since this species is distributed in West Java, dominant on Mount Malabar, West Java and top dominant tree species in Mount Gede Pangrango National Park (Soepadmo, E., van Steenis 1972). It is probably due to limited seed dispersal due to smaller seed size than other Castanopsis. Additionally, it is not edible and does not adapt to the environmental conditions optimum for growth such as low soil $\mathrm{pH}$ and light intensity.

Castanopsis javanica is well associated with other species in this remnant forest since it exists in all life forms. It is possible that $C$. javanica can facilitate the growth and reproduction of other species in the vicinity. It has a unique root system type forming a circular outline surrounding the tree facilitating and enhancing association with neighboring species. Results of this study conform with the previous report of Wihermanto (2004), that $C$. javanica can associate positively with the endangered species Saurauia bracteosa, Saurauia cauliflora, Rhododendron album and Symplocos costata in Mount Gede Pangrango National Park.

According to Jaccard index, the pair $C$ javanica and $C$. tungurrut at the sapling stage have the highest maximum association level of 0.2 (near to 1 as the maximum) compared with other pairs (below 0.1). The type of association is positive $\mathrm{a}>\mathrm{E}(\mathrm{a})$ as indicated in equation seven and it is associated since $x^{2}(4.24)$ is more than 3.84 . On the tree stage, however, the type of association of the pair is positive but not associated since $x^{2}(0.16)$ is less than $x$ table 3.84. Results revealed that both species occurred in all sampling sites, clumped in small numbers and do the interspecific association by facilitation and forming herd protection as described in interspecific association of tree species in China (Lan et al. 2012). Their association has a great impact to the existence of each species in the remnant forest and supports their capacity to alleviate environmental stresses. 
Table 4. Association tests using chi-squared test statistic $\left(x^{2}\right)$ and association index (Jaccard Index) between species in genus Castanopsis

\begin{tabular}{|c|c|c|c|c|c|}
\hline Life form & Paired species & $\begin{array}{l}\text { Chi- } \\
\text { square }\end{array}$ & $\begin{array}{c}\text { Type of } \\
\text { association } \\
\text { (positive / } \\
\text { negative) } \\
\end{array}$ & $\begin{array}{c}\text { Jaccard } \\
\text { index } \\
\text { (degree of } \\
\text { association) }\end{array}$ & $\begin{array}{c}\text { Associated/not } \\
\text { associated (based } \\
\text { on the chi-square } \\
\text { test) }\end{array}$ \\
\hline \multirow[t]{3}{*}{ Tree } & Castanopsis argentea $\mathrm{x}$ Castanopsis javanica & 0.77 & - & 0.04 & Not Associated \\
\hline & Castanopsis argentea $\mathrm{x}$ Castanopsis tungurrut & 2.65 & - & 0 & Not Associated \\
\hline & Castanopsis javanica $\times$ Castanopsis tungurrut & 0.16 & + & 0.08 & Not Associated \\
\hline \multirow[t]{3}{*}{ Saplings } & Castanopsis argentea $\mathrm{x}$ Castanopsis javanica & 1.21 & - & 0 & Not Associated \\
\hline & Castanopsis argentea $\mathrm{x}$ Castanopsis tungurrut & 0.83 & - & 0 & Not Associated \\
\hline & Castanopsis javanica $\mathrm{x}$ Castanopsis tungurrut & 4.24 & + & 0.2 & Associated \\
\hline Seedlings & Castanopsis argentea $\mathrm{x}$ Castanopsis javanica & 0.03 & - & 0 & Not Associated \\
\hline
\end{tabular}

Note: $x$ table $=3.84$

In conclusion, the vegetation of Cibodas remnant forest is dominated by tree pioneer species $O$. paniculata and $O$. integrifolia. The implication of domination of those species does not affect the presence of Castanopsis in the forest. The findings reported here showed that Castanopsis argentea is one of the Fagaceae members with the highest importance value in the Cibodas remnant forest, especially on the tree stage. While, it is contrary on the sapling and seedlings stratum, Castanopsis is less dominant probably due to the low germination capacity, predation and competition with the dominant introduced species in the forest floor. The succession of Cibodas remnant forest contributed to the aggregation of Castanopsis. Interspecific association within genus Castanopsis revealed that not all the species are associated. These results cast some doubts on the belief that Castanopsis commonly grow in clumps. It was only $C$. javanica and $C$. tungurrut that had a positive association with a Jaccard index of 0.2 . The association revealed that the occurrence of the species could enhance the composition of vegetation and ecosystem health by providing nutrition and shelter. Further study should be conducted to find the competition details not described in this study such as the probable presence of the allelopathic compound in Castanopsis which might explain its dispersion pattern in the Cibodas remnant forest.

\section{ACKNOWLEDGEMENTS}

We are grateful to Muhammad Efendi, Nudin, and Ujang Rustandi for field assistance and taxonomic support. The Director of Cibodas Botanical Garden, Indonesia issued the permit to conduct the study in the remnant forest. The study was supported by SEAMEO-SEARCA scholarship and the University of the Philippines Los Bańos, Philippines.

\section{REFERENCES}

Agustina A, Zuhud EAM, Darusman LK. 2015. Karakteristik habitat tabat barito (Ficus deltoidea Jack) pada tumbuhan inangnya. Jurnal Penelitian Hutan dan Konservasi Alam 12 (1): 89-104. DOI: 10.20886/jphka.2015.12.1.89-104. [Indonesian]
Ana IG, Antonio GB, Virginia S, Jesús JS, José MOM. 2013. Intraspecific competition replaces interspecific facilitation as abiotic stress decreases: the shifting nature of plant-plant interactions. Perspect Plant Ecol Evol Syst 15 (4): 226-236. DOI: 10.1016/j.ppees.2013.04.001.

Aoki K, Ueno S, Kamijo T, Setoguchi H, Murakami N, Kato M, Tsumura Y. 2014. Genetic differentiation and genetic diversity of Castanopsis (Fagaceae), the dominant tree species in Japanese broadleaved evergreen forests, revealed by analysis of EST-Associated Microsatellites. PLoS ONE 9 (1): e87429. DOI: 10.1371/journal.pone.0087429.

Baokun, Xu et al. 2019. Studies on interspecific association of both Castanopsis orthacantha and Castanopsis delavayi communities at Jizu Mountain Yunnan Province. Acta Ecol Sin 43 (4): 77-84.

Brooker, Rob W, Callaghan TV. 1998. The balance between positive and negative plant interactions and its relationship to environmental gradients: a model. Oikos 81 (1): 196-207. DOI 10.2307/3546481.

Buajan S, Liu JF, He ZS, Feng XP, Muhammad A. 2018. Effects of gap size and locations on the regeneration of Castanopsis kawakamii in a subtropical natural forest, China. J Trop Sci 30 (1): 39-48. DOI: 10.26525/jtfs2018.30.1.3948.

Cheuk ML, Fischer GA. 2021. The impact of climate change on the distribution of Castanopsis (Fagaceae) species in South China and Indo-China region. Global Ecol Conserv 26: e01388. DOI: 10.1016/j.gecco.2020.e01388.

Chu J, Wenqi L, Honglin C, Wei L. 2020. Analysis of function and metabolic pathway of phosphorus-responsive genes of Castanopsis chinensis under low phosphorus stress. Guihaia 40 (8): 1132-1139.

Deb P, Sundriyal RC. 2017. Effect of seed size on germination and seedling fitness in four tropical rainforest tree species. Indian J For 40 (4): 313-22.

Dogra KS, Kohli RK, Sood SK. 2009. An assessment and impact of three invasive species in the Shivalik Hills of Himachal Pradesh, India. Intl J Biodivers Conserv 1 (1): 4-10. DOI: 10.5897/IJBC.9000010.

Efendi M, Azizah N, Supriyatna A, Destri. 2017. Keragaman jenis dan preferensi ekologi begonia liar di kawasan hutan sisa Kebun Raya Cibodas. Berita Biologi 16 (3): 233-241. DOI: 10.14203/beritabiologi.v16i3.2873. [Indonesian]

He ZS, Tang R, Li MJ, Jin MR, Xin C, Liu JF, Hong W. 2020. Response of photosynthesis and chlorophyll fluorescence parameters of Castanopsis kawakamii seedlings to forest gaps. Forests 11 (1): 21. DOI: 10.3390/f11010021.i.

Heriyanto NM, Reny Sawitri, Didi S. 2016. Kajian ekologi permudaan saninten (Castanopsis argentea (B1.) A.DC.) di Taman Nasional Gunung Gede Pangrango, Jawa Barat. Buletin Plasma Nutfah 13 (1): 34-42. DOI: 10.21082/blpn.v13n1.2007. [Indonesian]

Hilwan I, Irfani E. 2018. Pola penyebaran dan regenerasi jenis saninten (Castanopsis argentea Blume) di Resort Selabintana, Taman Nasional Gunung Gede Pangrango. Silvikultur Tropika - Journal of Tropical Silviculture Science and Technology 9 (1): 53-59. DOI: $10.29244 / \mathrm{j}$ siltrop.9.1.53-59. [Indonesian]

Jin MR, Wang Z, He ZS, Jiang L, Liu JF, Lan YQ, Shi YW, Shen, CX. 2019. Allelopathic effect of Castanopsis kawakamii forest litter on seed germination of small Philippine Acacia (Acacia confusa). Appl 
Ecol Environ Res $17 \quad$ (6): 15103-15116. DOI 10.15666/aeer/1706_1510315116.

Junaedi, Decky Indrawan. 2012. Invasive plants in mountainous remnan forest: recommendation for choosing best decision for invasive species management of Cestrum aurantiacum Lindl. Buletin Kebun Raya 15 (1): 37-46. [Indonesian]

Kalima, Titi. 2007. keragaman jenis dan populasi flora pohon di hutan lindung Gunung Slamet, Baturraden, Jawa Tengah. Jurnal Penelitian Hutan dan Konservasi Alam 4 (2): 151-60. DOI: 10.20886/jphka.2007.4.2.151-160. [Indonesian]

Lan G, Getzin S, Wiegand T, Hu Y, Xie G, Zhu H, Cao M. 2012. Spatial distribution and interspecific associations of tree species in a tropical seasonal rain forest of China. PLoS ONE 7 (10): e46074. DOI: 10.1371/annotation/974531b0-9da4-4575-b3d1-955b0163fde0.

Larpkern, Panadda, Moe SR, Totland O. 2011. Bamboo dominance reduces tree regeneration in a disturbed tropical forest. Oecologia 165 (1): 161-68. DOI: 10.1007/s00442-010-1707-0.

Li C, Li XW, Li JQ. 2013. Taxonomic notes on Castanopsis (Fagaceae, Castaneoideae) from China. Phytotaxa 146 (2): 50-60. DOI: 10.11646/phytotaxa.146.2.2.

Liu MQ, Deng M, Zhou ZK. 2009. Taxonomic and ecological implications of leaf cuticular morphology in Castanopsis, Castanea and Chrysolepis. Plant Syst Evol 283: 111-23. DOI: 10.1007/s00606009-0220-6.

Lu Z, Zhiyao SU, Beiguang C. 2007. Interspecific relationships in the forest community dominated by pinus Kwangtungensis, an endangered species endemic to China. Acta Ecol Sin 2 (2): 128-35. DOI: $10.1007 / \mathrm{s} 11461-007-0021-4$

Mansur M, Hidayati N, Juhaeti T. 2011. Struktur dan komposisi vegetasi pohon serta estimasi biomassa, kandungan karbon dan laju fotosintesis di Taman Nasional Gunung Halimun-salak. Jurnal Teknik Lingkungan 12 (2): 161-69. DOI: $\quad$ 10.29122/jtl.v12i2.1248. [Indonesian]

Mutaqien Z, Zuhri m. 2011. Establishing a long-term permanent plot in remnant forest of Cibodas Botanic Garden, West Java. Biodiversitas 12 (4): 218-24. DOI: 10.13057/biodiv/d120406.

Phengklai C. 2006. A synoptic account of the Meliaceae of Thailand. Thai for Bull (Bot) 34: 53-175.

Pielou EC. 1972. 2k Contingency tables in ecology. J Thoer Biol 34: 337 352. DOI: $10.1016 / 0022-5193(72) 90166-X$

Purwaningsih, Polosakan R. 2016. Keanekaragaman Jenis dan sebaran Fagaceae di Indonesia. Ethos (Jurnal Penelitian dan Pengabdian Masyarakat) 4 (1): $\quad 85-92 . \quad$ DOI: $\quad 10.29313 /$ ethos.v0i0.1687. [Indonesian]

Raymundo D, Prado-Junior J, de Oliveira-Neto NE, Santana LD, do Vale VS, Jacobson TB, de Oliveira PEAM, Carvalho. 2018. Persistence of coffea arabica and its relationship with the structure, species diversity and composition of a secondary forest in Brazil. PLoS ONE 13(3): e0194032. DOI: 10.1371/journal.pone.0194032.

Rozak AH, Astutik S, Mutaqien Z, Widyatmoko D, Sulistyawati. 2017. hiperdominansi jenis dan biomassa pohon di Taman Nasional Gunung Gede Pangrango, Indonesia. J For Sci 11 (1): 85-96. DOI: 10.22146/jik.24903.

Shrestha B, Sharma RP, Bhandari SK. 2018. Individual tree aboveground biomass for Castanopsis indica in the Mid-Hills of Nepal. Agrofo Syst 92 (6): 1611-1623. DOI: 10.1007/s10457-017-0109-2.

Simbolon H. 2001. The growth dynamics on tree species of Fagaceae family in a tropical montane rain forest of West Java, Indonesia Berita Biologi 5 (6): 659-666. [Indonesian]
Soepadmo E, van Steenis CGGJ. 1972. Fagaceae in Flora Malesiana Vol. 7 (1). Wolters-Noordhoff Publications, Netherlands.

Su SJ, He ZS, Zheng SQ, Hong W Xu DW. 2015. Ecological species groups and interspecific association of dominant tree species in Daiyun Mountain National Nature Reserve. J Mount Sci 12 (3): 637 646. DOI: $10.1007 / \mathrm{s} 11629-013-2935-7$.

Trammell TLE, Ralston HA, Scroggins SA, Carreiro MM. 2012. Foliar production and decomposition rates in urban forests invaded by the exotic invasive shrub, Lonicera maackii. Biol Invasions 14 (3): 529545. DOI: $10.1007 / \mathrm{s} 10530-011-0093-9$.

Uromi MG, Berlyn GP, Gregoire TG, Tennakoon KU, Ashton MS. 2014. Differences in survival and growth among tropical rain forest pioneer tree seedlings in relation to canopy openness and herbivory. Biotropica 46 (2): 183-193. DOI: 10.1111/btp.12088.

Wang R, Compton SG, Chen XY. 2011. Fragmentation can increase spatial genetic structure without decreasing pollen-mediated gene flow in a wind-pollinated tree. Mol Ecol 20 (21): 4421-4432. DOI: 10.1111/j.1365-294X.2011.05293.x.

Wang R, Shi YS, Zhang YX, Xu GF, Shen GC, Chen XY. 2019. Distance-dependent seed-seedling transition in the tree Castanopsis sclerophylla is altered by fragment size. Commun Biol 2 (1): 1-10. DOI: 10.1038/s42003-019-0528-x

Wang ZF, Lian JY, Huang GM, Ye YH, Cao HL, Wang ZM. 2012. Genetic groups in the common plant species Castanopsis chinensis and their associations with topographic habitats. Oikos 121 (12): 2044-2051. DOI: 10.1111/j.1600-0706.2012.20483.x.

Whitten AJ, Whitten T, Soeriaatmadja RS, Soeriaatmadja RE, Afiff SA. 1996. 2 Ecology of Java \& Bali. Oxford University Press.

Wibowo C. 2006. Hubungan antara Keberadaan Saninten dengan Beberapa Sifat Tanah: Kasus di Taman Nasional Gunung Gede Pangrango, Jawa Barat. [Indonesian]

Wihermanto. 2004. Dispersion pattern interspecific association and population status of threatened plants on submontane and montane zones of Mount Gede-Pangrango National Park. Biodiversitas 5 (1): 17-22. DOI: $10.13057 /$ biodiv/d050104.

Xia Q, Ando M, Seiwa K. 2016. Interaction of seed size with light quality and temperature regimes as germination cues in 10 temperate pioneer tree species. Funct Ecol 30 (6): 866-874. DOI: 10.1111/13652435.12584.

Xu GL, Cai, WL 2016. Interspecific association of the dominant plant populations of Castanopsis community in Jiulianshan Nature Reserve, Jiangxi. Subtrop Plant Sci 45: 57-62.

Yamada I. 1977. Forest ecological studies of the montane forest of Mt. Pangrango, West Java: IV. Floristic composition along the altitude. Jpn J Southeast Asian Stud 15 (2): 226-254.

Ye S, Hu H, Huang H, Vargas-Mendoza CF. 2014. Chloroplast diversity and population differentiation of Castanopsis fargesii (Fagaceae): a dominant tree species in evergreen broad-leaved forest of subtropical China. Tree Genet Gen 10 (6): 1531-1539. DOI: 10.1007/s11295014-0776-3.

Zhang W. 2014. Interspecific associations and community structure: a local survey and analysis in a grass community interspecific associations and community structure. Selforganizology 1 (2): 89129.

Zuhri, Musyarofah. 2017. Asosiasi Balanophora elongata Blume dengan tumbuhan bawah di hutan kawasan Kebun Raya Cibodas. Seminar Nasional Biologi (SEMABIO) 2017, UIN Sunan Gunung Djati, Bandung, Indonesia. [Indonesian] 